\title{
FAKTOR-FAKTOR YANG MEMPENGARUHI PERSEPSI AKSEPTOR TERHADAP KUALITAS PELAYANAN KELUARGA BERENCANA DI PUSKESMAS DI MASA KRISIS
}

\author{
Oleh: \\ Fifit Isnafiah dan Sriadi Setyowati \\ Jurusan Pendidikan Geografi FISE UNY
}

\begin{abstract}
ABSTRAK
Penekitian ini bertujuan: 1) mengetahui hubungan antara pendidikan, pendapatan, dan pengalaman ber-KB dengan persepsi klien terhadap kualitas pelayanan KB di puskesmas di masa krisi; 2) mengetahui dimensi kualitas pelayanan KB yang paling penting bagi klien; 3) mengetahui harapan klien tentang kualitas pelayanan $K B$.

Wawancara dilakukan secara sensus terhadap semua responden yang berjumlah 114 akseptor, yang memiliki status sosial ekonomi prasejahtera dan sejahtera I. Metode penelitian yang digunakan adalah kuantitatif dengan teknik analisis deskriptif dan korelasi dan regresi ganda.

Hasil analisis deskriptif menunjukkan bahwa sebagian besar responden mempunyai persepsi yang baik terhadap kualitas pelayanan $K B$ Puskesmas di masa krisis. Persepsi tersebut dipengaruhi oleh tingkat pendidikan, tingkat pendapatan, dan pengalaman ber-KB. Dilihat dari harapan klien tentang pelayanan KB yang berkualitas baik, terdapat 27,2\% responden yang menjawab lebih suka memilih petugas pelayanan $K B$ yang mampu menjelaskan permasalahan dengan jelas dan mudah dimenegerti, 26,3\% memilih petugas KB yang ramah dan sabar. Jika dua gejala tersebut dicermati secara bersama-sama terlihat bahwa dimensi kualitas informasi dan dimnesi hubungan interpersonal antara pelayanan dengan dengan klien merupakan pilihan kebutuhan yang penting bagi klien. Dilihat dari hasil analisis korelasi dan regresi ganda, dari faktor pendidikan, pendapatan dan pengalaman ber-KB ternyata hanya faktor pengalaman ber-KB yang tidak memiliki hubungan yang signifikan terhadap persepsi tentang pelayanan ber-KB. Koefisien dterminan variabel pendapatan sebesar 12,1\% merupakan angka tertingi dibanding dengan dua variabel lainnya. Selanjutnya menunjukkan bahwa variansui persepsi terhadap kualitas layanan KB dapat disumbang oleh kedua faktor tersebut sebesar $10,7 \%$, sedangkan $89,3 \%$ ditentukan oleh faktor lain.
\end{abstract}

Kata kunci: persepsi, akseptor, KB, kualitas layanan 
Faktor-F Aktor Yang Mempengaruhi Persepsi Akseptor Terhadap Kualitas

Pelayanan Keluarga Berencana Di Puskesmas Di Masa Krisis

\section{Pendahuluan}

Pemahaman terhadap struktur umur merupakan hal penting dalam perencanaan pembangunan. Dalam suatu kelompok masyarakat, komposisi penduduk menurut umur sangat penting artinya baik dilihat aspek biologis, sosial maupun ekonomi. Komposisi penduduk menurut umur dapat digunakan untuk memperkirakan beberapa hal antara lain jumlah penduduk usia sekolah, jumlah penduduk usia kerja, maupun dapat digunakan untuk melihat angkat rasio ketergantungan.

Dalam bidang kependudukan terutama dalam analisis pemakaian terhadap alat kontrasepsi, umur merupakan variabel yang juga penting karena umur dapat menjadi indikator kematangan seorang perempuan secara biologis terutama mempengaruhi kesuburan. Menurut Yusril (1989) menyatakan bahwa masa subur atau masa reproduksi seseorang perempuan dapat dipengaruhi oleh tingkat kesehatan dan gizi seseorang tersebut. Hal ini bisa mengakibatkan masa reproduksi seorang perempuan dimulai lebih awal dari 15 tahun dan berakhir lebih lama dari 49 tahun, begitu juga sebaliknya. Namun pada umumnya masa subur atau masa reproduksi yang dimulai dari manarche (pertama kali menstruasi) sampai monopause terjadi pada umur 15-49 tahun. Sedang puncak kesuburan seorang perempuan diperkirakan pada umur 25-29 tahun. Tanpa mengesampingkan kelompok usia tua, kelompok usia produktif ini merupakan kelompok yang sedang memiliki tingkat kesuburan tinggi, yang kebutuhan akan pelayanan keluarga berencana (KB) sangat tinggi. Di Indonesia kelompok ini diharapkan ikut bertanggungjawab atau setidaktidaknya mendukung kelangsungan program KB.

\section{Metode Penelitian}

Penelitian ini merupakan penelitian deskriptif kuantitaif. Populasi penelitian yang berjumlahPengumpulan data dilakukan dengan cara wawancara. Wawancara dilakukan terhadap semua responden yang berjumlah 114 akseptor, yang memiliki status sosial ekonomi prasejahtera dan sejahtera I. Teknik analisis deskriptif dan korelasi product moment dan regresi ganda.

\section{Hasil Penelitian}

Hasil penelitian menunjukkan bahwa umur responden diperoleh kisaran terendah 20 tahun dan tertinggi 47 tahun dengan rata-rata 28 tahun. Proporsi terbesar ditempati oleh kelompok umur 25-29 tahun yakni sebesar 28,1\%, sedang proporsi terendah ditempati kelompok umur 40-44 tahun yakni sebesar 8,8\%. Jika mengamati Tabel 5.1 menunjukkan bahwa proporsi terbesar pada kelompok umur 25-29 tahun dan 35-39 tahun, hal 
Geomedia, Volume 5, Nomor 1, Mei 2007 ||

ini dimungkinkan mereka secara efektif ingin menunda lebih dahulu anak berikutnya, yang biasanya pada kelompok umur tersebut sudah mempunyai anak satu atau dua orang. Jadi alat/metode kontrasepsi semata-mata hanya untuk menunda kelahiran, sedang pada kelompok umur lebih tua yaitu 35 tahun ke atas, mereka lebih efektif lagi menggunakan alat kontrasepsi karena mereka sudah betul-betul tidak ingin menambah anak lagi. Jadi kebutuhan terhadap metode/alat kontrasepsi cenderung terpenuhi untuk membatasi kelahiran. Selain itu, data ini mencerminkan adanya kesadaran masyarakat terhadap usia kawin pertama.

1. Jumlah dan Persentase Responden Menurut

Tabel 1. Kelompok Umur dan Jumlah Anak Masih Hidup

\begin{tabular}{|c|c|c|}
\hline Kelompok Umur & $\mathrm{N}$ & Persentase \\
\hline $20-24$ & 13 & 11,4 \\
$25-29$ & 32 & 28,1 \\
$30-34$ & 20 & 17,5 \\
$35-39$ & 24 & 21,1 \\
$40-44$ & 10 & 8,8 \\
$45-49$ & 15 & 13,1 \\
\hline Jumlah & 114 & 100,00 \\
\hline Rata-rata umur & \multicolumn{2}{|}{} \\
\hline Jumlah anak & 71 & \\
\hline $1-2$ & 43 & 37,72 \\
\hline Jumlah & 114 & 100,00 \\
\hline Rata-rata & \multicolumn{2}{|c|}{} \\
\hline
\end{tabular}

Sumber: Data primer, 2001

2. Karakteristik Sosial Ekonomi

a. Tingkat Pendidikan

Dalam analisis demografi, pendidikan merupakan suatu perubahan sosial, misalnya untuk analisa fertilitas. Pendidikan dalam penelitian ini dilihat dari tahun sukses pendidikan formal yang ditempuh oleh responden. Dari data yang dikumpulkan mengenai tingkat pendidikan responden angka tertinggi yang diapai adalah 15 tahun sukses, sedang angka terendah yang dicapai adalah 1 tahun sukses. Dari data tersebut didapatkan nilai rata-rata tahun sukses pendidikan sebesar 8,54 dan standart deviasi sebear 3,48. 
Faktor-F Aktor Yang Mempengaruhi Persepsi Akseptor Terhadap Kualitas

Pelayanan Keluarga Berencana Di Puskesmas Di Masa Krisis

Dalam penelitian ini peneliti ingin melihat tingkat pendidikan responden menjadi tiga tingkatan yaitu rendah, sedang dan tinggi. Kelompok terendah adalah < mean -0,5 x standart deviasi atau 8,54-0,5 x 3,48 $=<$ 6,8 tahun sukses. Kelompok sedang adalah mean $-0,5 \times$ standart deviasi sampai dengan mean $+0,5 \times$ standart deviasi atau 6,8 - 10,28 tahun sukses. Sedang kelompok tinggi adalah $>$ mean $+0,5 \times$ standart deviasi atau 8,54 + $0,5 \times 3,48=>10,28$ tahun sukses.

Tabel 2 menunjukkan persentase jenjang pendidikan responden. Sebagian besar responden berpendidikan tinggi yaitu sebesar 37,7 persen atau 43 orang. Selanjutnya kelompok pendidikan rendah yaitu sebesar $35,1 \%$ atau 40 orang. Dari jumlah tersebut hanya ada 6 orang (15\%) yang tingkat pendidikannya hanya menempuh hingga kelas I (satu) SD. Sedang responden yang tingkat pendidikan sedang sebesar 31 orang $(27,2 \%)$ dan yang tamat SLTP sebesar 23 orang (79,3\%).

Tabel 2 Jumlah dan Persentase Responden Menurut Tingkat Pendidikan

\begin{tabular}{|c|c|c|}
\hline Tingkat Pendidikan & N & $\%$ \\
\hline Rendah $(<6,8)$ & 40 & 35,1 \\
\hline Sedang $(6,8-10,28)$ & 31 & 27,2 \\
\hline Tinggi $(>10,28)$ & 43 & 37,7 \\
\hline Jumlah & 114 & 100,00 \\
\hline \multicolumn{2}{|c|}{ Rata-rata pendidikan 8,54 tahun } \\
\hline \multicolumn{2}{|c|}{ Nilai standart deviasi 3,48 } \\
\hline
\end{tabular}

Sumber: Data primer, 2001

Dilihat dari uraian di atas menunjukkan bahwa tingkat pendidikan responden, secara keseluruhan merata atau seimbang, jadi tidak ada perbedaan yang mencolok antara pendidikan rendah, sedang dan tinggi. Dengan demikian dimungkinkan, meskipun responden merupakan keluarga pra sejahtera dan keluarga sejahtera tahap I, tetapi faktor pendidikan merupakan kebutuhan yang sangat penting. Hal ini diduga karena tingkat pendidikan merupakan faktor penting sebagai persyaratan-persyaratan dalam memasuki sektor-sektor pekerjaan yang terdapat di perkotaan, misalnya pelayan toko, perdagangan, dan jasa.

1. Menurut Lapangan Pekerjaan

Disamping faktor pendidikan yang dianggap berpengaruh terhadap penangkapan informasi, pengetahuan, sikap dan persepsi responden adalah faktor pekerjaan. Hal ini dikemukakan atas dasar pemikiran bahwa responden yang bekerja di luar rumah berpeluang besar untuk mendapatkan informasi lebih banyak dibanding responden yang tidak 
bekerja (sebagai ibu rumahtangga) dan yang bekerja di rumah. Didukung dengan hasil penelitian yang dilakukan Laurentina (1992) menunjukkan bahwa tingginya persentase isteri PUS yang bekerja (non pertanian) di perkotaan diduga dapat merubah motivasi isteri PUS untuk memiliki jumlah anak yang diinginkan. Hal ini disebabkan wanita yang bekerja pada umumnya mempunyai pendidikan yang lebih tinggi daripada wanita yang tidak bekerja. Disamping itu ada beberapa faktor yang mempengaruhi seseorang akan memasuki suatu bidang pekerjaan tertentu selain faktor tingkat pendidikan, faktor kesempatan kerja yang ada di suatu daerah maupun tingkat ketrampilan yang dimiliki, juga sangat menentukan.

Dalam penelitian ini jenis pekerjaan/kegiatan isteri PUS atau responden dikelompokkan menjadi dua kelompok utama yakni tidak bekerja dan bekerja, yang bekerja selanjutnya dibedakan lagi menurut jenis pekerjaannya. Untuk lebih jelasnya dapat dilihat pada Tabel 3.

Tabel 3. Jumlah dan Persentase Responden Menurut Lapangan Pekerjaan

\begin{tabular}{|l|c|c|}
\hline Pekerjaan & $\mathrm{N}$ & $\%$ \\
\hline Tidak bekerja/ibu rumahtangga & 88 & 77,19 \\
\hline Bekerja: & & \\
\hline - bekerja di rumah & 6 & 3,51 \\
\hline - pedagang & 4 & 3,51 \\
\hline - pekerja (bergaji/upahan) & 14 & 12,28 \\
\hline - lainnya & 114 & 1,76 \\
\hline Jumlah & & 100,00 \\
\hline
\end{tabular}

Sumber: Data primer, 2001

Tabel 3 di atas terlihat bahwa secara keseluruhan sebagian besar responden/isteri PUS tidak bekerja atau sebagai ibu rumah tangga yakni ada 88 orang $(77,19 \%)$. Hanya sebagian kecil yang bekerja sebagai pekerja upahan/ bergaji yakni sebesar 14 orang $(12,28 \%)$, sisanya bekerja di bidang perdagangan sebesar 3,51\%, dan bekerja/usaha di rumah sebesar 5,26\%.

Uraian di atas menarik yaitu di sisi lain sebagian besar responden mempunyai tingkat pendidikan tinggi yakni lulus SLTA, di lain sisi sebagian besar responden tidak bekerja atau sebagai ibu rumah tangga. Berdasarkan hasil penelitian di lapangan disebabkan karena (1) sebagian besar responden berusia 25-35 tahun dan masih mempunyai anak 1-2 orang yang masih kecil-kecil/balita. Jika mereka bekerja di luar rumah harus memakai jasa pembantu rumah tangga, sedang penghasilan keluarga tidak memungkinkan untuk membayarnya, sehingga dipilih untuk tidak bekerja dengan mengasuh anak-anaknya atau sebagai ibu rumah tangga, (2) mereka tidak mempunyai keahlian/ketrampilan tertentu. 
Faktor-F Aktor Yang Mempengaruhi Persepsi Akseptor Terhadap Kualitas

Pelayanan Keluarga Berencana Di Puskesmas Di Masa Krisis

Bagi responden yang ikut bekerja atau mencari nafkah ada dua kemungkinan yang menyebabkan, yaitu (1) ikut membantu meringankan beban ekonomi rumah tangga, sebab semakin banyaknya anak serta makin besarnya pengeluaran di satu pihak dan terbatasnya kemampuan suami mendapatkan penghasilan, (2) responden memang sejak sebelum berumahtangga telah bekerja dan punya perhatian untuk melakukan pekerjaan tersebut, sehingga apabila mereka tidak melakukan pekerjaan tersebut akan merasa kehilangan sesuatu.

\section{Pendapatan Keluarga}

Pendapatan yang digunakan dalam penelitian ini adalah mengacu pada rata-rata nilai pendapatan bersih yang diperoleh keluarga responden selama rentang waktu satu bulan. Dalam hal ini pendapatan, dalam arti luas diinterpretasikan sebagai jumlah seluruh pendapatan yang bersumber dari pendapatan pokok dan usaha sampingan atau sumber-sumber lainnya.

Dalam usaha menjaring data tersebut kiranya dapat disadari bahwa untuk mendapatkan derajat akurasi yang tinggi, merupakan hal yang tidak mudah, sebab keragaman dalam jenis pekerjaan akan berpengaruh pula terhadap pendapatan baik dalam jumlah maupun pola penerimaan. Disamping itu faktor kejujuran responden dalam memberikan jawaban yang sebenarnya. Tidak menutup kemungkinan pada saat wawancara dan pengisian kuesioner dilaksanakan terdapat beberapa responden berpendapatan tinggi menjawab dengan pendapatan rendah, atau sebaliknya responden yang berpendapatan rendah mengaku berpendapatan tinggi. Kalau seorang pegawai negeri mempunyai pola penerimaan yang teratur setiap bulan dan dalam jumlah relatif tetap, sedangkan pedagang dan buruh akan menerima pendapatan tidak menentu. Disamping itu masih belum meluasnya kebiasaan membuat catatan tentang pendapatan keluarga, maka pengumpulan datanya menjadi agak rumit.

Walaupun banyak menghadapi kendala dalam memperoleh data yang sebenarnya lewat referensi pendekatan rata-rata pendapatan yang mereka peroleh per kurun waktu tertentu, hasil penelitian ini menunjukkan pendapatan responden cukup bervariasi yaitu antara Rp 225.000,- - Rp 750.000,-. Dengan rata-rata pendapatan per bulan $\mathrm{Rp} 420.700$,- dan standart deviasi sebesar 170.720. Untuk mengukur tingkat pendapatan dilihat dari nilai/angka yang diperoleh. Berdasarkan rentang nilai yang diperoleh dibuat klasifikasi secara sederhana menjadi tiga tingkatan yaitu:

$$
\begin{array}{ll}
<\mathrm{Rp} \mathrm{335.340} & =\text { tingkat pendapatan rendah } \\
\mathrm{Rp} 335.340-\mathrm{Rp} \mathrm{506.060} & =\text { tingkat pendapatan sedang } \\
>\operatorname{Rp} 506.060 & =\text { tingkat pendapatan tinggi }
\end{array}
$$


Dalam klasifikasi menjadi tiga tingkatan ini adalah berdasarkan tujuan dari peneliti, bahwa peneliti ingin melihat tingkatan pendapatan itu menjadi tiga tingkat yaitu rendah, sedang dan tinggi. Adapun dasar penentuan nilai dari tiga tingkatan ini dilakukan dengan dasar mean (Rp 420.700) dan standart deviasi (170.720). kelompok terendah adalah < mean - 0,5 x standart deviasi atau $420.700-0,5 \times 170.720=<335.340$. Kelompok sedang adalah mean $-0,5 \times$ standart deviasi sampai dengan mean +0.5 x standart deviasi atau Rp 335.340 - Rp506.060,-. Sedang kelompok tinggi adalah $>$ mean $+0,5 \times$ standart deviasi atau $\mathrm{Rp} 420.700+$ $0,5 \times 170.720=>\operatorname{Rp} 506.060$ (lihat tabel 4).

Tabel 4. Jumlah dan Persentase PendapatanKeluarga Responden

\begin{tabular}{|c|c|c|}
\hline Pendapatan Keluarga & $\mathrm{N}$ & $\%$ \\
\hline Rendah (< Rp 335.340) & 65 & 57,0 \\
\hline Sedang (Rp 335.340 - Rp 506.060) & 16 & 14,0 \\
\hline Tinggi (> Rp 506.060) & 40 & 35,1 \\
\hline Jumlah Rata-rata pendapatan Rp. 420.700,- \\
\hline \multicolumn{2}{|c|}{ Nilai standart deviasi 170.720 } \\
\hline
\end{tabular}

Sumber: Data primer, 2001

Tabel 4 memperlihatkan bahwa sebagian besar pendapatan keluarga responden adalah rendah, yaitu sebesar 50,9\% (58 orang), sedang rumah tangga yang berpendapatan tinggi sebesar 35,1\% (40 orang). Hal ini diduga, mereka yang berpenghasilan rendah dan sedang, kepala rumah tangganya bekerja sebagai pekerja upahan/buruh, tukang becak, kaki lima dan lain-lain yang sejenisnya. Terbukti dalam penelitian ini suami responden yang bekerja sebagai pekerja upahan/bergaji sebesar $62,6 \%$ dan lainnya, seperti tukang becak, kaki lima sebesar 20,9\%. Sedang sisanya yang berpenghasilan tinggi diasumsikan sebagai pegawai negeri sipil, pedagang dan yang mempunyai usaha di rumah.

\section{Pengalaman Ber-KB}

Banyak faktor yang mempengaruhi seseorang untuk memanfaatkan atau tidak memanfaatkan tempat pelayanan yang ada. Lamanya memanfaatkan pelayanan dapat mengindikasikan kecocokan/kemantapan atau tidak seseorang dengan tempat pelayanan yang ada, dalam hal ini, responden yang memanfaatkan fasilitas Puskesmas di daerah yang bersangkutan. Disamping itu lamanya memanfaatkan tempat pelayanan tersebut merupakan salah satu faktor yang menunjang persepsi responden tentang kualitas pelayanan KB. Semakin lama akseptor memanfaatkan 
Faktor-F Aktor Yang Mempengaruhi Persepsi Akseptor Terhadap Kualitas

Pelayanan Keluarga Berencana Di Puskesmas Di Masa Krisis

tempat pelayanan tersebut diasumsikan persepsi akseptor terhadap kualitas pelayanannya semakin baik.

Hasil penelitian ini menunjukkan bahwa lamanya responden memanfaatkan pelayanan KB di puskesmas adalah mulai dari satu bulan sampai dengan 48 bulan (4 tahun, bulan Agustus 2001) dengan rata-rata lamanya memanfaatkan pelayanan adalah 26,51 bulan dan standart deviasi sebesar 15,4. Berdasarkan rentang angka/nilai tersebut dibuat klasifikasi secara sederhana menjadi tiga tingkatan, yakni $<18,81$ bulan (tingkat lamanya rendah), 18,81 - 34,21 bulan (tingkat lamanya sedang), > 34,21 bulan (tingkat lamanya tinggi).

Dasar penentuan nilai/angka dari setiap tingkatan dilakukan dengan dasar mean $(26,1)$ dan standart deviasi $(15,4)$. Kelompok rendah adalah < mean - 0,5 x standart deviasi atau 26,51 - 0,5 x 15,4 = < 18,81 bulan. Kelompok sedang adalah mean $-0,5 \times$ standart deviasi sampai dengan mean $+0,5 \times$ standart deviasi atau 18,81 - 34,21 bulan. Sedang kelompok tertinggi adalah $>$ mean $+0,5 \times$ standart deviasi atau $26,51+0,5 \times 15,4=>34,21$ bulan. Untuk melihat gambaran/distribusi mengenai pengalaman ber-KB dapat dilihat pada Tabel 5 berikut.

Tabel 5. Jumlah dan Persentase Pengalaman Ber-KB

\begin{tabular}{|l|c|c|}
\hline Pengalaman ber-KB & $\mathrm{N}$ & $\%$ \\
\hline Rendah (<18,81 bulan) & 46 & 40,4 \\
Sedang (18,81 - 34,21 bulan) & 18 & 15,8 \\
Tinggi $(>34,21$ bulan) & 50 & 43,9 \\
\hline Jumlah & 114 & 100,0 \\
\hline \multicolumn{2}{|c|}{ Rata-rata 26,51 bulan } \\
\hline \multicolumn{2}{|c|}{ Standart deviasi 15,4 } \\
\hline
\end{tabular}

Sumber: Data primer, 2001

\section{Persepsi terhadap Kualitas Pelayanan KB}

Kualitas pelayanan KB terdiri dari enam elemen pelayanan yakni: pilihan terhadap metode/alat kontrasepsi, kualitas informasi untuk akseptor, hubungan interpersonal antara akseptor dan petugas pelayanan, kompetensi petugas pelayanan, mekanisme pelayanan lanjutan, dan akseptabilitas/ ketepatan pelayanan. Untuk mengetahui gambaran utuh mengenai persepsi akseptor tentang kualitas pelayanan $K B$ berikut ini adalah persepsi akseptor untuk setiap elemen pelayanan $K B$ serta harapan/keinginan akseptor tentang pelayanan KB yang berkualitas. 
1. Pilihan terhadap Metode Kontrasepsi

Pilihan terhadap metode kontrasepsi diharapkan menjadi pilihan terbaik bagi akseptor. Hal ini dikarenakan pertama, akseptor dalam pemakaian alat kontrasepsi memiliki berbagai tujuan yaitu mengatur jarak kelahiran dan membatasi kelahiran. Kedua, akseptor dalam pemakaian alat kontrasepsi mungkin memiliki kerentanan yang berbeda-beda tergantung dengan kondisi fisik dan biologis mereka. Dengan demikian, pusat pelayanan KB yang baik harus mampu memberi akses yang sama terhadap berbagai jenis alat kontrasepsi kepada para akseptor, yang selanjutnya akan sangat menentukan kepuasan akseptor dan kelangsungan akseptor KB dalam pemakaian alat kontrasepsi.

Pilihan terhadap metode kontrasepsi ini diukur dengan menggunakan tujuh pertanyaan sebagai indikator dengan dua alternatif pilihan jawaban. Nilai akhir adalah berkisar antara 1 sampai 14, hasil analisis menunjukkan angka terbesar 14 dan terkecil 7 dengan nilai ratarata 12,3509 . Temuan ini mengindikasikan bahwa pilihan terhadap metode kontrasepsi sudah terpenuhi meskipun masih belum sempurna.

Tabel 6 menunjukkan bahwa dari rincian jawaban per indikator tampak ada beberapa indikator yang masih kurang menurut persepsi akseptor. Indikator tersebut terutama kemungkinan mengganti kontrasepsi jika tidak puas lagi dengan pilihan semula, kemudian petugas dalam memberitahu kontrasepsi (baik jenis maupun variasinya) yang tersedia, serta indikator pilihan (kontrasepsi) tersebut umumnya tersedia.

Dalam penelitian ini jenis/metode kontrasepsi yang dipakai responden saat ini, secara keseluruhan sebagian besar jenis kontrasepsi suntik yang merupakan pilihan responden yaitu 31,6\%, kemudian IUD sebesar $28,9 \%$, pil sebesar $23,7 \%$, serta norplant sebesar $14,0 \%$. Hanya sebagian kecil dari responden yang memilih kondom sebagai alat kontrasepsi yaitu sebesar 1,8\%. Secara ringkas dapat dilinat pada Tabel 6 .

Tabel 6. Persepsi terhadap Pilihan Metode Kontasepsi

\begin{tabular}{|c|c|c|}
\hline Indikator & $N=114$ & $\%$ \\
\hline \multicolumn{3}{|l|}{$\begin{array}{l}\text { Petugas memberikan jenis kontrasepsi yang } \\
\text { tersedia }\end{array}$} \\
\hline Tidak & 43 & 37,7 \\
\hline $\mathrm{Ya}$ & 71 & 62,3 \\
\hline Total & 114 & 100,0 \\
\hline \multicolumn{3}{|l|}{ Kontrasepsi tersebut merupakan pilihan ibu } \\
\hline Tidak & 17 & 14,9 \\
\hline Ya & 97 & 85,1 \\
\hline Total & 114 & 100,0 \\
\hline
\end{tabular}

95 
Faktor-F Aktor Yang Mempengaruhi Persepsi Akseptor Terhadap Kualitas

Pelayanan Keluarga Berencana Di Puskesmas Di Masa Krisis

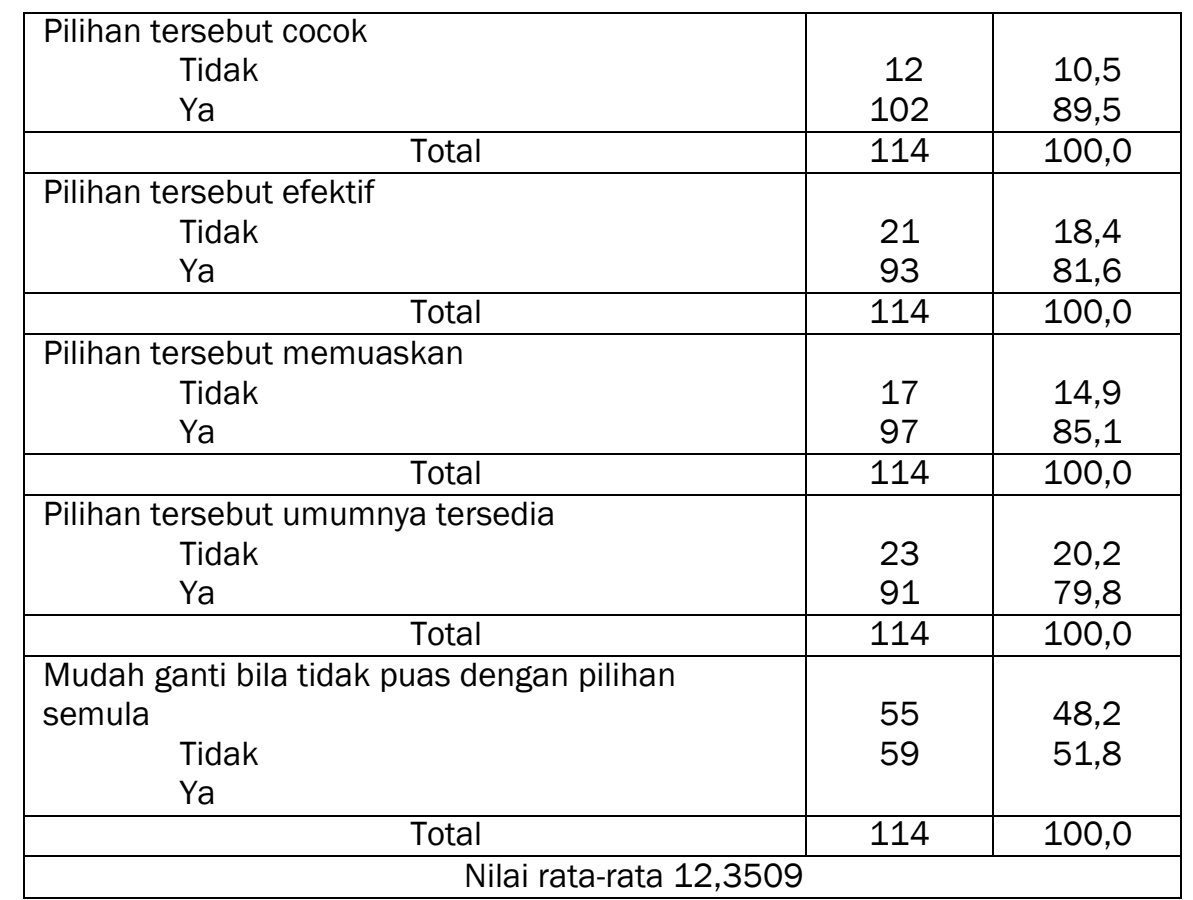

Sumber: Data primer, 2001

Tabel 7. Jenis/Metode Kontrasepsi yang Dipakai saat ini

\begin{tabular}{|l|c|c|}
\hline Jenis/metode kontrasepsi & N & $\%$ \\
\hline Pil & 27 & 23,7 \\
\hline IUD & 33 & 28,9 \\
\hline Suntik & 36 & 31,6 \\
\hline Norplant & 16 & 14,0 \\
\hline Kondom & 2 & 1,8 \\
\hline Jumlah & 114 & 100,0 \\
\hline
\end{tabular}

Sumber: Data primer, 2001

Dari uraian di atas jika dikaitkan dengan beberapa indikator yang menonjol pada persepsi akseptor terhadap pilihan terhadap metode kontrasepsi dan kondisi di masa krisis ini, ada beberapa hal yang menarik dan perlu dikaji. Di antaranya ditemukannya metode suntik merupakan pilihan sebagian besar responden meskipun hampir seimbang dengan metode kontrasepsi IUD. Jika dikaitkan dengan kondisi di masa krisis ini, di mana metode suntik harus membayar dan responden merupakan keluarga pra sejahtera, keluarga sejahtera tahap I yang untuk mencukupi kebutuhan sehari-hari sangat pas-pasan ternyata sangat peduli dengan kebutuhan metode/alat kontrasepsi, sebagai alat pencegah kehamilan. 
Disamping itu mereka yang memiliki metode suntik, sebagian dari responden merasa sudah cocok (89,5\%) dan efektif (81,6\%) (Tabel 5.6) meskipun sebagian besar dari mereka tidak datang bulan. Didukung oleh pemahaman sebagian besar dari mereka terutama tentang IUD dan susuk/norplant, adanya rasa ketakutan akan lepas, keluhan saat bersenggama dengan suami, baik dari pihak suami (iritasi pada alat kelaminnya) atau pada diri sendiri (darah menstruasi semakin banyak), rasa risih ketika dilakukan pemasangan, serta belum memahami sepenuhnya cara bekerja alat/metode kontrasepsi misalnya metode susuk/implant.

Bagi responden yang memilih memakai alat kontrasepsi IUD maupun implant pada umumnya mereka ikut program safari KB yang dilakukan di puskesmas dan tidak membayar, serta pengetahuan mereka sebagian besar tentang jenis kontrasepsi sangat terbatas, terlihat dari jawaban mereka tentang macam-macam jenis kontrasepsi. Di samping itu, sebagian dari mereka merasa sudah cocok dan efektif terutama jenis IUD tidak mengakibatkan flek-flek hitam di wajah tidak mengubah bentuk badan, praktis dan tidak perlu sering mengganti.

Menurut tabel 6 sebesar 51,8\% responden yang mengemukakan mudah mengganti metode/alat kontrasepsi yang lain. Hal ini menunjukkan bahwa tidak semua akseptor dalam pemakaian terhadap alat/metode kontrasepsi sesuai dengan keinginannya.

2. Kualitas Informasi untuk Akseptor

Kualitas informasi untuk akseptor merupakan unsur penting dalam menilai kualitas pelayanan KB secara umum. Artinya informasi yang lengkap yang diberikan oleh pemberi layanan kepada akseptor tentang cara-cara penggunaan, memperoleh, serta efek samping alat yang mungkin timbul akan memberikan wawasan yang ikut menentukan kemampuan akseptor untuk memutuskan pilihannya secara tepat. Dengan demikian pilihan terhadap alat/metode kontrasepsi secara tepat diharapkan mampu memberikan kepuasan dan perasaan aman yang optimal bagi akseptor sehingga kelangsungan pemakaian kontrasepsi dapat ditingkatkan.

Kualitas informasi berkisar antara 1 sampai dengan 14. Hasil analisis menunjukkan bahwa angka terbesar 14 dan terkecil 7 dengan nilai rata-rata 10,3333. Temuan ini mengindikasikan bahwa kualitas informasi yang diberikan provider kepada akseptor belum cukup memuaskan. Padahal pelayanan kontrasepsi yang berkualitas adalah informasi lengkap yang memberikan wawasan kepada akseptor tentang berbagai kemungkinan metode/alat yang dapat dipilih, efek samping, kontraindikasi dan kapan alat-alat tersebut dapat dipakai. Dengan demikian kualitas informasi merupakan bagian pokok dalam pelayanan KB. 
Faktor-F Aktor Yang Mempengaruhi Persepsi Akseptor Terhadap Kualitas

Pelayanan Keluarga Berencana Di Puskesmas Di Masa Krisis

Tabel 8 Persepsi terhadap Kualitas Informasi

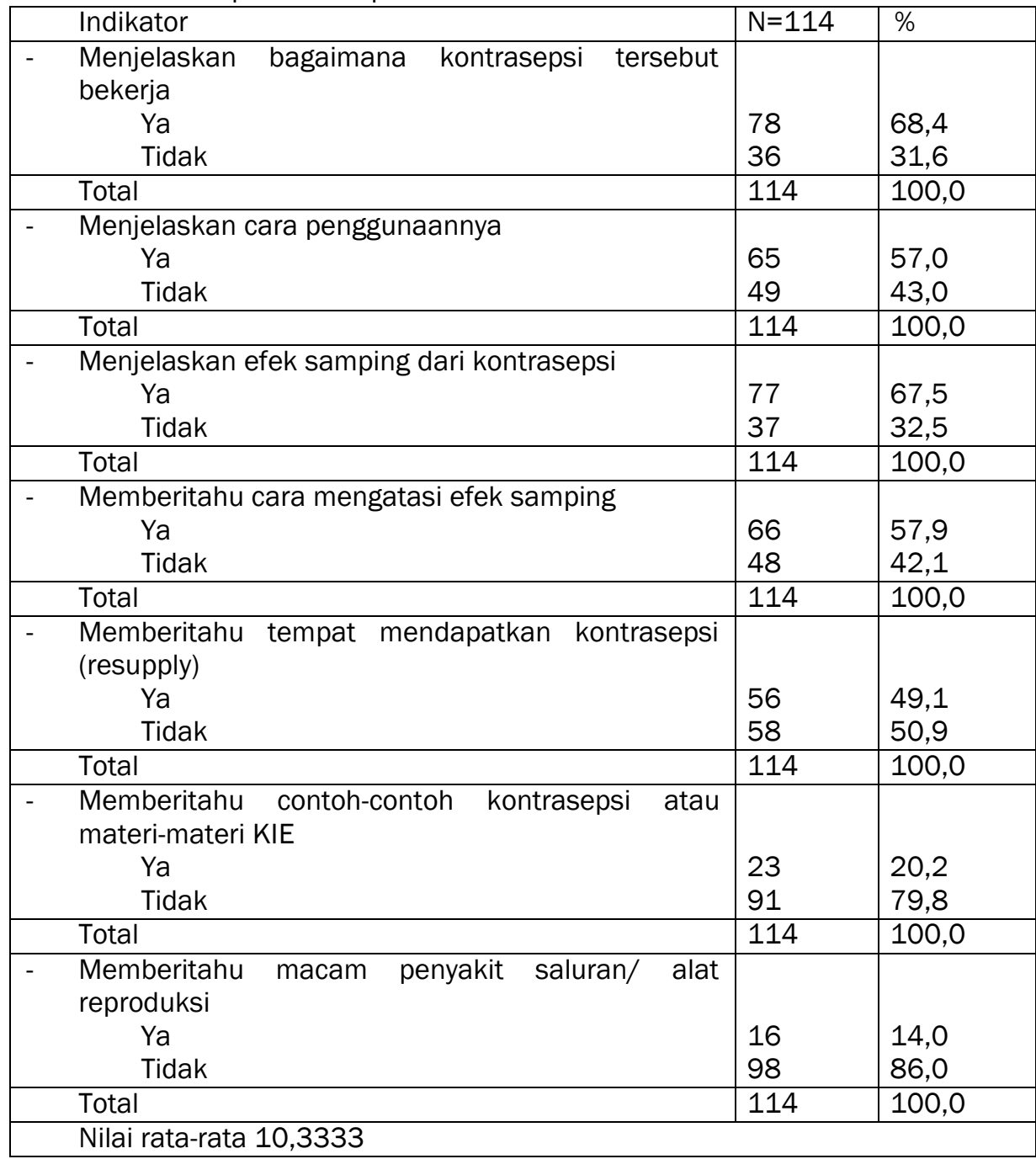

Sumber: Data primer, 2001

Dari rincian jawaban per indikator pada Tabel 8 tampak bahwa secara umum akseptor memperoleh informasi tentang macam-macam alat kontrasepsi, namun persentasenya hanya kecil. Misalnya informasi tentang cara kerja kontrasepsi $(68,4 \%)$, cara penggunaannya $(57,0 \%)$, efek samping dari kontrasepsi $(67,5 \%)$ serta cara mengatasi efek samping tersebut $(57,9 \%)$. Selain itu hasil penelitian di lapangan para responden umumnya 
memperoleh informasi tentang manfaat, efek samping, kontraindikasi serta langkah-langkah yang harus diambil jika terjadi efek samping justru mereka peroleh dari orang lain atau pengalaman mereka sendiri. Didukung tingkat pendidikan responden yang lebih baik, hal ini memungkinkan responden lebih mampu berkomunikasi dengan orang lain, yang pada akhirnya mereka lebih mampu menyerap informasi yang mereka terima dan sekaligus mampu menyeleksi informasi yang mereka butuhkan terutama dari petugas pelayanan. Responden yang menjawab adanya pemberitahuan dari petugas tentang tempat mendapatkan kontrasepsi kembali/resupply sebesar $49,1 \%$, contoh-contoh kontrasepsi atau materi-materi KIE sebesar 20,2\% serta berbagai penyakit saluran/alat kontrasepsi hanya sebesar $14,0 \%$.

Hasil penelitian di lapangan menunjukkan bahwa rendahnya contohcontoh kontrasepsi atau materi-materi KIE dimungkinkan karena para petugas pelayanan KB merasa di Puskesmas sudah terdapat beberapa poster dan gambar-gambar KIE seperti poster tentang hak-hak akseptor dalam memilih kontrasepsi, poster kampanye KB. Namun, gambar atau poster tersebut tidak cukup diperhatikan dan dipahami oleh akseptor KB, bahwa hal tersebut sebenarnya merupakan penyuluhan yang secara tidak langsung dan sangat bermanfaat bagi para akseptor KB.

Sedang penjelasan petugas mengenai macam-macam penyakit saluran/ alat reproduksi, seperti penyakit seksual menular, infeksi saluran reproduksi, HIV, AIDS sangat jarang diberitahukan kepada akseptor $\mathrm{KB} / a k s e p t o r$. Apalagi penyakit-penyakit yang mungkin terjadi karena efek samping dari metode/alat kontrasepsi. Hal ini disebabkan karena para petugas pelayanan KB beranggapan bahwa dengan diberikannya informasi tentang efek samping, kontraindikasi, atau problem-problem kesehatan yang terjadi akibat efek samping metode/alat kontrasepsi, tidak jarang malah mengurangi motivasi akseptor atau akseptor untuk memakai alat/metode kontrasepsi. Pada akhirnya akseptor akan menunda atau bahkan tidak memakai alat kontrasepsi. Selain itu, para responden umumnya juga tidak berusaha untuk menanyakan hal tersebut. Di pihak lain, pelayanan kontrasepsi yang berkualitas baik harus memberikan wawasan kepada akseptor tentang berbagai kemungkinan jenis/metode/alat kontrasepsi yang dapat dipilih, efek samping, kontraindikasi, kapan alat tersebut telah dipakai, serta problem-problem kesehatan yang terjadi akibat efek samping metode/jenis/alat kontrasepsi.

3. Hubungan Interpersonal antara Petugas dan Akseptor

Faktor lain yang perlu dicermati dan sangat menunjang dalam pembentukan kualitas pelayanan KB secara umum yaitu kualitas hubungan antarpersonal antara petugas pelayanan dengan akseptor. Hal ini disebabkan karena salah satu segi penekanan yang sangat diperhatikan 
Faktor-F Aktor Yang Mempengaruhi Persepsi Akseptor Terhadap Kualitas

Pelayanan Keluarga Berencana Di Puskesmas Di Masa Krisis

oleh akseptor yaitu apakah pemberian pelayanan KB tersebut berkualitas baik atau tidak, dilihat dari sejauh mana petugas/pemberi layanan dapat berkomunikasi dengan baik dan dapat memuaskan akseptor.

Hubungan interpersonal antara petugas dan akseptor dalam penelitian ini diukur dengan menggunakan 8 pertanyaan sebagai indikator dengan 3 alternatif jawaban. Nilai terkecil adalah 1 dan nilai terbesar adalah 16. Hasil analisis menunjukkan bahwa angka terbesar 16 dan terkecil 8 dengan nilai rata-rata 13,7281 . Temuan ini mengindikasikan bahwa hubungan interpersonal antara petugas pelayanan dengan akseptor secara keseluruhan cukup baik meskipun masih belum sempurna.

Dari rincian jawaban per indikator pada Tabel 9 ada dua indikator yang mendapatkan persentase yang lebih rendah dibandingkan dengan enam indikator lainnya. Kedua indikator tersebut yaitu kenyamanan yang dirasakan oleh akseptor pada saat konsultasi sebesar $59,6 \%$ dan tersedianya waktu saat konsultasi sebesar $69,3 \%$. Jika dilihat dari dua indikator ini secara bersama-sama, terlihat bahwa dengan waktu konsultasi yang terbatas, akan sangat sulit akseptor memperoleh informasi yang memadai, dengan alasan terbatasnya waktu konsultasi menyebabkan akseptor merasa tidak nyaman untuk bertanya. Di pihak lain karena akseptor merupakan keluarga miskin (keluarga pra sejahtera dan sejahtera tahap I) dimungkinkan adanya jarak sosial antara akseptor dengan petugas sehingga akseptor merasa tidak nyaman untuk bertanya secara intensif terutama tentang keluhan-keluhan yang mereka derita saat sedang berkonsulstasi. Di samping itu, hasil penelitian di lapangan menunjukkan adanya sebagian responden yang menyatakan bahwa pemberi layanan kadang-kadang tidak tanggap dan hanya menampung keluhan yang akseptor sampaikan dan tidak memberikan jalan pemecahannya, sehingga akan mengurangi keeratan hubungan mereka.

Tabel 9. Persepsi terhadap Hubungan Interpersonal antara Petugas dan Akseptor

\begin{tabular}{|l|l|l|}
\hline Indikator & $\mathrm{N}=114$ & $\%$ \\
\hline$-\quad$ Petugas ramah dan menghargai akseptor & & \\
Ya & 100 & 87,7 \\
Tidak & 14 & 12,3 \\
\hline Total & 114 & 100,0 \\
\hline Petugas mempersilahkan akseptor bertanya & & \\
Ya & 83 & 72,8 \\
Tidak & 31 & 27,2 \\
\hline Total & 114 & 100,0 \\
\hline Penjelasan petugas bisa dimengerti & & \\
Ya & 97 & 85,0 \\
\hline
\end{tabular}


Geomedia, Volume 5, Nomor 1, Mei 2007 ||

\begin{tabular}{|c|c|c|}
\hline Tidak & 17 & 15,0 \\
\hline Total & 114 & 100,0 \\
\hline $\begin{array}{l}\text { Cukup waktu saat berkonsultasi } \\
\text { Ya } \\
\text { Tidak }\end{array}$ & $\begin{array}{l}79 \\
35\end{array}$ & $\begin{array}{l}69,3 \\
30,7\end{array}$ \\
\hline Total & 114 & 100,0 \\
\hline $\begin{array}{l}\text { - Akseptor percaya dengan nasehat petugas } \\
\text { Ya } \\
\text { Tidak }\end{array}$ & $\begin{array}{l}97 \\
17\end{array}$ & $\begin{array}{l}85,1 \\
14,9\end{array}$ \\
\hline Total & 114 & 100,0 \\
\hline $\begin{array}{l}\text { - } \quad \text { Petugas tidak bersikap menggurui } \\
\text { Ya } \\
\text { Tidak }\end{array}$ & $\begin{array}{l}95 \\
19\end{array}$ & $\begin{array}{l}83,3 \\
16,7\end{array}$ \\
\hline Total & 114 & 100,0 \\
\hline $\begin{array}{l}\text { - } \quad \text { Petugas cukup sabar } \\
\text { Ya } \\
\text { Tidak }\end{array}$ & $\begin{array}{l}99 \\
15\end{array}$ & $\begin{array}{l}86,8 \\
13,2\end{array}$ \\
\hline Total & 114 & 100,0 \\
\hline $\begin{array}{l}\text { - } \quad \text { Akseptor merasa nyaman saat konsultasi } \\
\text { Ya } \\
\text { Tidak }\end{array}$ & $\begin{array}{l}68 \\
46\end{array}$ & $\begin{array}{l}59,6 \\
40,4\end{array}$ \\
\hline Total & 114 & 100,0 \\
\hline
\end{tabular}

Sumber: Data primer, 2001

Hasil penelitian di lapangan menunjukkan bahwa hubungan interpersonal antara pemberi layanan dan akseptor juga ditentukan oleh jenis kelamin pemberi layanan. Hal ini ditemukannya dari 114 responden terdapat 106 responden yang menjawab lebih suka dilayani oleh petugas wanita dengan alasan mereka merasa lebih cocok, lebih terbuka, lebih bebas menyampaikan keluhan serta tidak merasa malu. Di samping itu memiliki pengalaman-pengalaman yang berkaitan dengan kelahiran atau problem-problem penyakit saluran reproduksi. Sedang responden yang menjawab tidak ada perbedaan antara petugas perempuan maupun laki-laki sebanyak 6 responden. Mereka beralasan bahwa yang paling penting yaitu mereka yang mempunyai keahlian dalam bidangnya sehingga bisa memberikan pelayanan KB yang berkualitas dan maksimal.

\section{Persepsi terhadap Kemampuan Teknis Petugas}

Salah satu faktor penting dalam penilaian akseptor KB/akseptor terhadap kualitas pelayanan KB yaitu kemampuan teknis petugas dalam memberikan pelayanan kontrasepsi. Faktor ini akan sangat mempengaruhi 
Faktor-F Aktor Yang Mempengaruhi Persepsi Akseptor Terhadap Kualitas

Pelayanan Keluarga Berencana Di Puskesmas Di Masa Krisis

akseptor dalam memanfaatkan pelayanan yang diberikan dan untuk memperoleh pelayanan KB yang berkualitas dan maksimal.

Dalam penelitian ini, indikator yang dipakai untuk mengukur persepsi tentang kemampuan teknis petugas pelayanan adalah prosedurprosedur standart sederhana yang seharusnya dilakukan juga seorang akseptor melakukan konsultasi atau kontrol. Hal ini dikarenakan kemampuan teknis petugas pelayanan merupakan faktor yang paling sulit diukur, apalagi dilihat dari persepsi akseptor. Ada 4 pertanyaan sebagai indikatornya dengan 2 alternatif jawaban, untuk mengukur persepsi akseptor terhadap kemampuan teknis petugas pelayanan. Nilai terkecil adalah 1 dan nilai terbesar adalah 8. Hasil analisis menunjukkan bahwa nilai terkecil yang diperoleh adalah 4 dan nilai terbesar adalah 8 dengan nilai rata-rata 6,2895 . Temuan ini mengindikasikan bahwa adanya kondisi di mana kemampuan teknis petugas pelayanan sudah terpenuhi meskipun masih belum sempurna.

Dari rincian jawaban per indikator pada Tabel 10 tampak bahwa hampir semua indikator dirasakan masih kurang menurut pandangan responden. Indikator yang menonjol adalah apakah petugas pelayanan bertanya tentang intensi reproduksi (misal: keluhan-keluhan fisik akibat efek samping) (50\%) dan pemeriksaan fisik (49,2\%). Hasil di lapangan menunjukkan bahwa sebagian responden mengemukakan adanya pemeriksaan yang lengkap dari petugas pelayanan KB seperti pemeriksaan fisik, pemeriksaan tekanan darah, cek lapangan medis. Jika akseptor memiliki problem-problem khusus/keluhan- keluhan akibat efek samping alat/metode kontrasepsi. Di samping itu, beberapa responden menyatakan bahwa petugas pelayanan sudah hafal pada dirinya sehingga tidak dilakukan pemeriksaan pendahuluan. Hal ini dikemukakan oleh sebagian besar responden yang menggunakan metode/alat kontrasepsi suntik.

Tabel 5.10. Persepsi terhadap Kemampuan Teknis Petugas

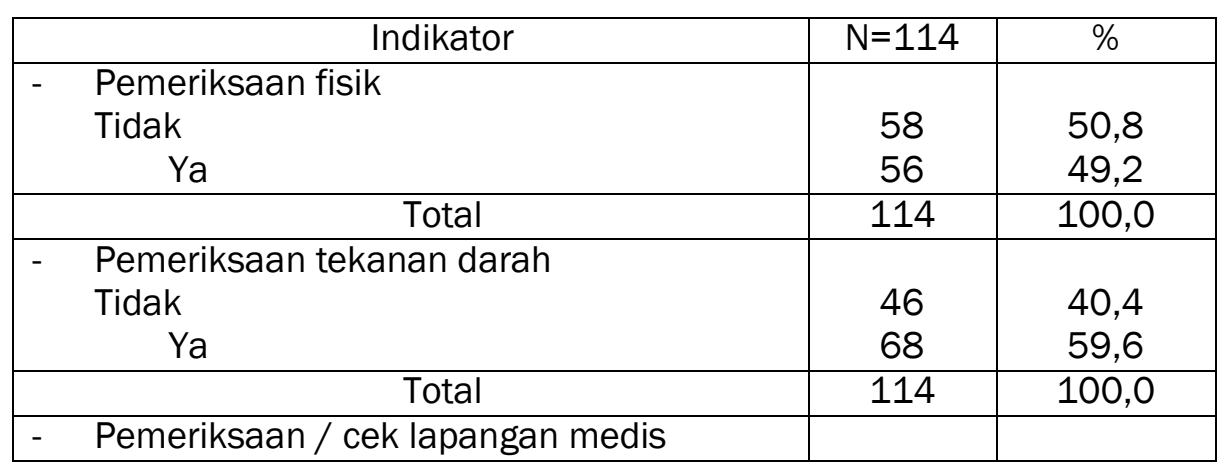


Geomedia, Volume 5, Nomor 1, Mei 2007 ||

\begin{tabular}{|c|c|c|}
\hline Tidak & 34 & 29,8 \\
\hline Ya & 80 & 70,2 \\
\hline Total & 114 & 100,0 \\
\hline $\begin{array}{ll}\text { - } & \text { Bertanya tentang intensi reproduksi (misal: } \\
& \text { keluhan-keluhan fisik) }\end{array}$ & & \\
\hline Tidak & 57 & 50,0 \\
\hline Ya & 57 & 50,0 \\
\hline Total & 114 & 100,0 \\
\hline
\end{tabular}

Sumber: Data primer, 2001

\section{Persepsi terhadap Mekanisme Pelayanan Lanjutan}

Mekanisme pelayanan lanjutan adalah salah satu indikator kualitas pelayanan KB yang berguna untuk mengukur kualitas pelayanan yang diberikan kepada akseptor, setelah akseptor menjadi akseptor dalam rangka mendorong keberlangsungan pemakaian kontrasepsi. Pelayanan lanjutan berguna untuk memonitor akseptor agar tidak terjadi hal-hal yang tidak diinginkan, terutama untuk menangani secara dini jika terjadi keluhankeluhan akibat efek samping atau ketidakcocokan terhadap pemakaian alat/jenis kontrasepsi tertentu. Dengan demikian, dampak negatif penggunaan alat/jenis kontrasepsi dapat diperkecil dan akseptor menjadi merasa aman dan yakin dalam memakainya sehingga mendorong keberlangsungan pemakaian kontrasepsi.

Ada 3 item pertanyaan indikator yang dipakai untuk mengukur persepsi terhadap mekanisme pelayanan lanjutan dengan 2 alternatif jawaban. Nilai terkecil adalah 1 dan nilai terbesar adalah 6. Hasil lapangan menunjukkan bahwa nilai terkecil adalah 3 dan nilai terbesar 6 dengan nilai rata-rata adalah 5,3333. Hasil ini menunjukkan bahwa mekanisme pelayanan lanjutan yang diberikan kepada akseptor sudah cukup memuaskan meskipun belum sempurna.

Tolak ukur dari mekanisme pelayanan lanjutan, dapat dilihat dari ada tidaknya usaha-usaha dari petugas pelayanan KB dalam mengefektifkan upaya tindak lanjut secara rutin, alat-alat bantu yang digunakan, serta kemudahan-kemudahan yang diberikan kepada akseptor dalam memperoleh pelayanan lanjutan. Berdasarkan rincian jawaban terlihat pada Tabel 5.11. Dari 114 responden terdapat 87,7\% yang menyatakan bahwa petugas pelayanan memberitahu waktu untuk kontrol atau harus berkunjung berikutnya, dan sebesar $78,9 \%$, jika kontrasepsi tidak tersedia, petugas pelayanan memberitahu tempat dan cara mendapatkannya. Satu indikator yang persentasenya lebih rendah dari 2 indikator lainnya yaitu petugas pelayanan KB dalam menggunakan kartu 
Faktor-F Aktor Yang Mempengaruhi Persepsi Akseptor Terhadap Kualitas

Pelayanan Keluarga Berencana Di Puskesmas Di Masa Krisis

kontrol atau prosedur lainnya hanya sebesar $67,5 \%$. Petugas pelayanan KB dalam melakukan kunjungan rumah dilakukan secara rutin di saat mereka belum menjadi akseptor, namun setelah menjadi akseptor KB mereka jarang melakukan kunjungan rumah. Hal ini sangat disayangkan oleh beberapa responden karena kunjungan rumah dengan tujuan hanya memotivasi calon akseptor agar mau memakai salah satu metode/alat kontrasepsi. Padahal harapan responden, kunjungan rumah yang dilakukan oleh petugas pelayanan KB tetap dilakukan agar dapat mudah teratasi, jika terjadi keluhan-keluhan akibat efek samping dari pemakaian kontrasepsi.

Tabel 11. Persepsi terhadap Mekanisme Pelayanan Lanjutan

\begin{tabular}{|c|c|c|}
\hline Indikator & $\mathrm{N}=114$ & $\%$ \\
\hline $\begin{array}{l}\text { - Jika kontrasepsi tidak tersedia, petugas memberitahu } \\
\text { tempat dan cara mendapatkannya } \\
\text { Ya } \\
\text { Tidak }\end{array}$ & $\begin{array}{l}90 \\
24\end{array}$ & $\begin{array}{l}78,9 \\
21,1\end{array}$ \\
\hline Total & 114 & 100,0 \\
\hline $\begin{array}{l}\text { - Petugas memberitahu harus berkunjung berikut- } \\
\text { nya/waktu kontrol } \\
\text { Ya } \\
\text { Tidak }\end{array}$ & $\begin{array}{r}100 \\
14\end{array}$ & $\begin{array}{l}87,7 \\
12,3\end{array}$ \\
\hline Total & 114 & 100,0 \\
\hline $\begin{array}{l}\text { - } \quad \text { Petugas menggunakan kartu kontrol atau sejenisnya } \\
\text { Ya } \\
\text { Tidak }\end{array}$ & $\begin{array}{l}77 \\
37\end{array}$ & $\begin{array}{l}67,5 \\
32,5\end{array}$ \\
\hline $\begin{array}{l}\text { Total } \\
\text { Nilai rata-rata } 5.3333\end{array}$ & 114 & 100,0 \\
\hline
\end{tabular}

Sumber: Data primer, 2001

\section{Persepsi terhadap Ketepatan dan Akseptabilitas Pelayanan}

Ketepatan dan akseptabilitas pelayanan KB adalah kondisi pelayanan KB yang dapat diterima, mudah diperoleh termasuk kebutuhan terhadap kontrasepsi dan memenuhi kebutuhan akseptor. Hal ini sangat berhubungan dengan perasaan responden/akseptor yang bisa menimbulkan rasa sangat puas, puas dan tidak puas.

Hasil analisis data lapangan menunjukkan bahwa nilai terkecil adalah 7 dan nilai terbesar 12 dengan nilai rata-rata sebesar 11,1228. Temuan ini mengindikasikan bahwa ketepatan dan akseptabilitas pelayanan 
Geomedia, Volume 5, Nomor 1, Mei 2007 ||

KB yang diberikan oleh petugas/pemberi layanan sudah cukup baik, artinya akseptor sudah merasa puas terhadap ketepatan/akseptabilitas pelayanan $\mathrm{KB} /$ pelayanan yang diberikan.

Tabel 12. Persepsi terhadap Ketepatan dan Akseptabilitas Pelayanan

\begin{tabular}{|c|c|c|c|}
\hline & Indikator & $\mathrm{N}$ & $\%$ \\
\hline- & $\begin{array}{l}\text { Akseptor mendapatkan pelayanan yang diinginkan } \\
\text { Puas }\end{array}$ & 100 & $\begin{array}{l}87,7 \\
12\end{array}$ \\
\hline & & & 12,3 \\
\hline & Total & 114 & 100,0 \\
\hline - & $\begin{array}{l}\text { Puas dengan waktu tunggu } \\
\text { Puas }\end{array}$ & 92 & 80,7 \\
\hline & Tidak puas & 22 & 19,3 \\
\hline & Total & 114 & 100,0 \\
\hline- & $\begin{array}{l}\text { Puas dengan jam kerja } \\
\text { Puas }\end{array}$ & 104 & 91,2 \\
\hline & Tidak puas & 10 & 8,8 \\
\hline & Total & 114 & 100,0 \\
\hline - & $\begin{array}{l}\text { Pelayanan yang bersifat rahasia/pribadi } \\
\text { Puas }\end{array}$ & 87 & 76,3 \\
\hline & Tidak puas & 27 & 23,7 \\
\hline & Total & 114 & 100,0 \\
\hline & $\begin{array}{l}\text { Puas dengan lingkungan fisik } \\
\text { Puas } \\
\text { Tidak }\end{array}$ & $\begin{array}{l}89 \\
25\end{array}$ & $\begin{array}{l}78,1 \\
219\end{array}$ \\
\hline & Total & 114 & 100,0 \\
\hline & $\begin{array}{l}\text { Secara umum, puas dengan pelayanan KB di } \\
\text { Puskesmas ini } \\
\text { Puas } \\
\quad \text { Tidak puas }\end{array}$ & $\begin{array}{c}102 \\
2\end{array}$ & $\begin{array}{l}98,2 \\
1,8\end{array}$ \\
\hline & Total & 114 & 100,0 \\
\hline - & $\begin{array}{l}\text { Jika teman/tetangga ingin } \mathrm{KB} \text {, responden } \\
\text { menyarankan memanfaatkan pelayanan KB di } \\
\text { Puskesmas ini } \\
\text { Puskesmas/klinik lain } \\
\text { Tidak menjawab }\end{array}$ & $\begin{array}{l}90 \\
18 \\
6\end{array}$ & $\begin{array}{r}78,9 \\
15,8 \\
5,3\end{array}$ \\
\hline & Total & 114 & 100,0 \\
\hline
\end{tabular}

Sumber: Data primer, 2001

Tabel 12 menunjukkan bahwa secara umum sebagian besar responden/ akseptor merasa puas terhadap ketepatan dan akseptabilitas 
Faktor-F Aktor Yang Mempengaruhi Persepsi Akseptor Terhadap Kualitas

Pelayanan Keluarga Berencana Di Puskesmas Di Masa Krisis

pelayanan KB yang diberikan petugas. Jika dilihat dari rincian jawaban per indikator pada Tabel 5.12 tampak bahwa ada beberapa indikator yang dirasakan masih kurang menurut persepsi responden/akseptor. Indikator yang paling menonjol mereka merasa tidak puas adalah pelayanan yang bersifat rahasia/pribadi sebesar $23,7 \%$ dan lamanya waktu tunggu sebesar $19,3 \%$. Hasil pengamatan di lapangan menunjukkan bahwa lamanya waktu tunggu disebabkan banyaknya antrian yang disebabkan tidak hanya dari akseptor KB tetapi dari berbagai pasien. Di samping itu, pelayanan di Puskesmas harus mengikuti birokrasi tertentu misalnya harus beli karcis, pendaftaran, baru ke bagian pelayanan KB. Selain itu pelayanan dari petugas tidak dimulai dari pagi atau awal jam kerja tetapi baru dimulai pada jam tertentu setelah dirasa pasiennya sudah cukup banyak. Hal yang menarik dan perlu dicermati yaitu adanya sebagian besar responden atau sebesar $78,9 \%$ yang menyarankan kepada teman/tetangga maupun saudara untuk memanfaatkan pelayanan KB di Puskesmas tempat mereka mendapatkan pelayanan. Temuan ini mengindikasikan bahwa responden/akseptor umumnya merasa puas dengan pelayanan yang diberikan petugas. Namun di sisi lain, diduga dipengaruhi oleh perasaan yang berkaitan dengan kesopanan yakni keengganan untuk menyampaikan sesuatu hal yang kurang menyenangkan di hadapan orang lain (Widaningrum, 1999). Selain itu diduga responden/akseptor tidak memiliki sebuah kerangka acuan khusus tentang bagaimana menilai sebuah pelayanan KB yang berkualitas baik. Dari 114 responden terdapat 5,3\% yang tidak memberi jawaban apa-apa, diduga mereka beranggapan bahwa pemilihan tempat pelayanan sangat tergantung pada kemantapan responden/akseptor masing-masing.

\section{Ekspektasi Akseptor tentang Pelayanan KB yang Berkualitas}

Dari Tabel 13 dapat dilihat bahwa jika dilihat lebih cermat, ternyata akseptor juga memiliki harapan-harapan yang sangat bervariasi tentang pelayanan KB yang selayaknya diterima. Jika dilihat jawaban per indikator tampak bahwa responden sebesar $27,2 \%$ lebih mementingkan/memilih petugas pelayanan KB yang mampu menjelaskan problem dengan jelas dan mudah dimengerti. Hal ini petugas pelayanan KB harus mampu menjelaskan alat/metode/jenis kontrasepsi atau masalah-masalah yang timbul sebagai akibat efek samping dari pemakaian kontrasepsi dengan jelas dan mudah dimengerti oleh responden/akseptor. Berdasarkan pengalaman akseptor, pemberi layanan jarang sekali memberikan informasi tentang kontraindikasi atau efek samping dari alat/metode/ jenis kontrasepsi yang ditawarkan, sehingga kemungkinan terjadi kesalahpahaman terhadap salah satu metode kontrasepsi. Di samping itu, beberapa responden menyatakan 
Geomedia, Volume 5, Nomor 1, Mei 2007 ||

bahwa petugas pelayanan kadang-kadang tidak tanggap dengan keluhan yang mereka sampaikan. Umumnya petugas pelayanan hanya menampung keluhan tersebut, namun tidak memberikan pemecahan.

Selain itu, ada $26,3 \%$ dari jumlah responden yang memilih petugas pelayanan KB yang ramah dan sabar, diduga mereka lebih mampu berkomunikasi dengan baik dan nyaman. Jika dua elemen ini dicermati secara bersama-sama terlihat sekali bahwa kualitas informasi dan hubungan interpersonal antara petugas pelayanan dengan akseptor merupakan kebutuhan yang sangat penting bagi akseptor KB.

Tabel 5.13. Ekspektasi Akseptor tentang Pelayanan KB yang Berkualitas Baik

\begin{tabular}{|l|c|c|}
\hline Harapan Akseptor tentang Pelayanan KB & N & $\%$ \\
\hline Petugas ramah dan sabar & 30 & 26,3 \\
\hline Waktu konsultasi memadai & 8 & 7,0 \\
\hline Bertanggungjawab & 2 & 1,8 \\
\hline Mau berdialog dengan akseptor/pasien & 8 & 7,0 \\
\hline Ketersediaan alat/metode kontrasepsi & 10 & 8,8 \\
\hline Pelayanan yang memuaskan & 9 & 7,9 \\
\hline Tempat pelayanan dekat & 2 & 1,8 \\
\hline Mampu menjelaskan problem dengan jelas & 31 & 27,2 \\
\hline Tidak memaksa akseptor/pasien & 14 & 12,3 \\
\hline Total & 114 & 100,0 \\
\hline
\end{tabular}

Sumber: Data primer, 2001

Indikator-indikator lain yang tidak begitu menonjol dan perlu diperhatikan dan dicermati, yaitu terdapatnya 12,3\% dari 114 responden yang menyatakan bahwa pelayanan $\mathrm{KB}$ yang berkualitas adalah di mana petugas tidak memaksa akseptor terhadap pemakaian suatu alat/metode kontrasepsi tertentu. Selain itu terdapat 8,8\% yang menyatakan ketersediaan alat/metode/jenis kontrasepsi di pusat pelayanan sangat diperlukan. Jika dua elemen ini diperhatikan secara bersama-sama terlihat bahwa pilihan terhadap metode kontrasepsi juga merupakan kebutuhan yang penting bagi akseptor KB. Di samping itu, berdasarkan pengamatan di lapangan, beberapa responden mengatakan hal ini berdasarkan pengalaman sebelum memanfaatkan pusat pelayanan ini dimana mengikuti program safari KB yang biasanya kinerja program KB tersebut berusaha mencapai target sasaran akseptor KB, dalam hal ini menekankan pada penekanan jumlah target akseptor, terutama untuk akseptor kontrasepsi IUD dan implant. 
Faktor-F Aktor Yang Mempengaruhi Persepsi Akseptor Terhadap Kualitas

Pelayanan Keluarga Berencana Di Puskesmas Di Masa Krisis

\section{Simpulan}

Dengan demikian telah diuraikan di atas tentang profil persepsi responden atau akseptor KB untuk setiap komponen kualitas pelayanan KB di Puskesmas di masa krisis. Berdasarkan deskriptif kuantitatif dan informasi kualitatif, ada beberapa hal yang perlu diperhatikan, yaitu:

1. Komponen pilihan terhadap metode kontrasepsi sudah menunjukkan kondisi yang sudah terpenuhi dan memadai tetapi masih belum sempurna. Tidak sepenuhnya pilihan atas metode/alat kontrasepsi yang dipakai responden/akseptor KB didasarkan atas pengetahuan tentang kontrasepsi tersebut. Tidak jarang karena dorongan dan motivasi yang sangat kuat dari petugas layanan yang berusaha mencapai target sasaran akseptor untuk menjadi ukuran keberhasilan program terutama akseptor IUD dan implant.

2. Kualitas informasi yang diberikan petugas layanan kepada akseptor KB belum cukup memuaskan dan tidak banyak dipahami oleh akseptor KB. Padahal pelayanan kontrasepsi yang berkualitas adalah informasi yang lengkap yang memberikan wawasan kepada akseptor tentang berbagai kemungkinan metode/alat yang dapat dipilih, efek samping, kontra indikasi dan kapan alat-alat tersebut dapat dipakai. Berdasarkan pengalaman akseptor/ KB/akseptor di lapangan bahwa umumnya para responden memperoleh informasi tentang manfaat, efek samping, kontra indikasi serta langkah-langkah yang harus diambil jika terjadi efek samping akibat pemakaian kontrasepsi justru. mereka peroleh dari orang lain atau pengalaman mereka sendiri. Petugas pelayanan jarang memberikan informasi tentang efek samping dan kontra indikasi dari alat/metode kontrasepsi tersebut. Temuan ini menunjukkan bahwa konsultasi yang baik dan jelas serta mudah dimengerti hendaknya memperoleh prioritas yang utama dalam pemberian layanan KB. Didukung temuan dari harapan akseptor KB tentang pelayanan KB yang berkualitas di mana petugas pelayanan mampu menjelaskan problemproblem dengan jelas dan mudah dimengerti.

3. Hubungan interpersonal antara petugas pelayanan dengan akseptor secara keseluruhan cukup baik meskipun masih belum sempurna. Adanya sebagian responden menyatakan bahwa petugas pelayanan kadang-kadang tidak tanggap dan hanya menampung keluhan yang akseptor KB sampaikan tanpa harus mencari pemecahannya, sehingga akan mengurangi keeratan hubungan mereka. Fakta menunjukkan bahwa harapan akseptor tentang pelayanan KB yang berkualitas di mana petugas pelayanan KB ramah dan sabar. Dengan keramahan dan kesabaran petugas pelayanan, akseptor akan merasa lebih bebas dalam menyatakan keluhan dan pendapat tentang alat/ metode kontrasepsi 
yang akan dan sedang mereka pakai. Disamping itu responden lebih suka dilayani oleh petugas wanita karena lebih bisa berkomunikasi dan lebih bebas menyampaikan keluhan serta tidak merasa malu.

4. Kemampuan teknis petugas pelayanan, merupakan elemen yang paling sulit diukur, terutama dilihat dari persepsi akseptor.Temuan di lapangan menunjukkan hampir semua indikator dari kemampuan teknis petugas pelayanan dirasakan masih kurang menurut persepsi akseptor.. Sebagian responden mengemukakan adanya pemeriksaan yang lengkap dari petugas pelayanan jika akseptor memiliki problem-problem khusus/keluhan akibat efek samping dari pemakaian kontrasepsi.

5. Mekanisme pelayanan lanjutan yang diberikan petugas layanan kepada akseptor secara umum sudah cukup memuaskan meskipun masih belum sempurna. Fakta menunjukkan ada sebagian responden yang menyatakan bahwa ajakan/anjuran untuk melakukan kontrol secara teratur dari petugas pelayanan, terutama bagi akseptor yang baru saja memakai alat/metode kontrasepsi. Di samping itu, harapan responden, kunjungan rumah yang dilakukan oleh petugas pelayanan KB tetap dilakukan baik di saat akseptor belum menjadi akseptor maupun sesudah menjadi akseptor, agar dapat mudah teratasi jika terjadi keluhan-keluhan akibat efek samping dari pemakaian alat/metode kontrasepsi.

6. Akseptabilitas pelayanan KB yang diberikan petugas pelayanan kepada akseptor secara umum sebagian besar responden merasa puas, tetapi masih belum sempurna. Fakta menunjukkan pelayanan yang bersifat rahasia/pribadi dan lamanya waktu tunggu dinilai beberapa responden kurang memuaskan. Hal ini disebabkan banyaknya antrian dan harus melewati berbagai prosedur untuk memperoleh pelayanan di Puskesmas. Di samping itu, awal jam kerja baru di muka pada jam tertentu setelah dirasa pasiennya sudah banyak. 
Faktor-F Aktor Yang Mempengaruhi Persepsi Akseptor Terhadap Kualitas

Pelayanan Keluarga Berencana Di Puskesmas Di Masa Krisis

\section{Daftar Pustaka}

Laurentina, 1992. PUS yang bekerja di sektor non pertanian perkotaan dan motivasi iseri PUS untuk memiliki jumlah anak yang diinginkan. Tesis Pascasarjanan UGM. Tidak dipublikasikan.

Singarimbun, Masri dan Sofian Effendi, 1989. Metode Penelitian Survei. Jakarta : LP3ES.

Yusril, M., 1989. Pengaruh Tingkat Kesehatan dan Gizi Tehadap Masa Subur Perempuan. Tesisi Pascasarjana UGM. Tidak dipublikasikan. 